\title{
ANALISA ALIRAN DAYA SISTEM TENAGA LISTRIK PADA BAGIAN PENYULANG 05EE0101A DI AREA UTILITIES II PT. PERTAMINA (PERSERO) REFINERY UNIT IVCILACAP MENGGUNAKAN METODE NEWTON-RAPHSON
}

Fredo Otniel ${ }^{1}$, Nundang Busaeri ${ }^{2}$, Sutisna ${ }^{3}$

Teknik Elektro, Universitas Siliwangi, Tasikmalaya ${ }^{123}$ e-mail: fredo.otniel@gmail.com ${ }^{1}$

\begin{abstract}
Power flow analysis or commonly called load flow is very necessary to determine the condition of the electric power system in normal operating conditions, both those that are running and those expected to occur in the future. Power flow analysis carried out in this study used the Newton-Raphson method with the help of ETAP 12.6 software.Power flow analysis is carried out in two phases of testing, in the first stage under the conditions of the exiting system and in the second stage by making improvements as input for the system going forward. The first stage of the simulation results are several buses that underwent under voltage and over Cable 4 experienced overload, on feeder 05EE0101A in area utilities II, the total power generated by the generator was 6,618 MW and 3,068 MVAR, the largest power flow flowing from feeder 05EE0101A to bus3 was 3,694 MW and 1,661 MVAR, the total losses of all channels are 0.144 MW and 0.308 MVAR, and the largest voltage drop occurs on bus 05EE1228A at $6.71 \%$ of nominal voltage. In the second stage, to increase the optimal flow of power, a tap changer at the transformer and Cable4 change is done, the total active power increases by $0.014 \mathrm{MW}$ to $6,632 \mathrm{MW}$ and the total reactive power decreases by 0.009 MVAR to 3,059 MVAR, the total losses of all channels decrease by $0.010 \mathrm{MW}$ to 0.134 MW and 0.015 MVAR to 0.293 MVAR, and the voltage drop on the 05EE1228A bus has an optimization of an increase of $5.31 \%$ from the first stage and the voltage distribution rate for each bus reaches $98 \%$ to $100 \%$ operating voltage.
\end{abstract}

Keywords : ETAP, Newton-Raphson, Power Flow

Analisa aliran daya atau biasa disebut load flow sangat diperlukan untuk mengetahui kondisi sistem tenaga listrik pada keadaan pengoperasian normal, baik yang sedang berjalan maupun yang diharapkan akan terjadi di masa yang akan datang. Analisa aliran daya yang dilakukan pada penelitian ini menggunakan metode Newton-Raphson dengan bantuan software ETAP 12.6. Analisa aliran daya dilakukan dua tahap pengujian, pada tahap pertama dalam kondisi sistem eksiting dan pada tahap kedua dengan melakukan perbaikan sebagai masukan untuk sistem kedepannya. Hasil simulasi tahap pertama terdapat beberapa bus yang mengalami under voltage dan pada Cable4 mengalami overload, pada penyulang 05EE0101A di area utilities II didapat total daya yang dibangkitkan oleh generator sebesar 6.618 MW dan 3.068 MVAR, aliran daya terbesar mengalir dari penyulang 05EE0101A menuju bus3 sebesar 3.694 MW dan 1.661 MVAR, total losses seluruh saluran sebesar 0.144 MW dan 0.308 MVAR, dan drop tegangan terbesar terjadi pada bus 05EE1228A sebesar $6.71 \%$ dari tegangan nominal. Pada tahap kedua, untuk meningkatkan aliran daya yang optimal dilakukan tap changer pada trafo dan pergantian Cable4, didapatkan total daya aktif naik sebesar 0.014 MW menjadi 6.632 MW dan total daya reaktif turun sebesar 0.009 MVAR menjadi 3.059 MVAR, total losses seluruh saluran turun sebesar 0.010 MW menjadi 0.134 MW dan 0.015 MVAR menjadi 0.293 MVAR, dan drop tegangan pada bus 05EE1228A mengalami optimasi peningkatan sebesar $5.31 \%$ dari tahap pertama dan tingkat penyaluran tegangan setiap bus mencapai $98 \%$ sampai $100 \%$ tegangan operasi.

Kata Kunci : Aliran Daya, ETAP, Newton-Raphson

\section{PENDAHULUAN}

Semua unit industri di dunia membutuhkan energi listrik untuk melakukan proses produksi maupun distribusi. Di PT. Pertamina (Persero) Refinery Unit IV Cilacap memiliki unit utilities yang merupakan unit penunjang operasi sistem kelistrikan. Seiring bertambahnya beban, maka perubahan terhadap sistem tenaga listrik tak dapat terhindarkan. Tanpa adanya pengelolaan yang baik terhadap sistem kelistrikan, maka akan memperbesar rugi-rugi daya yang terjadi serta memperburuk profil tegangan. Akibatnya desain konfigurasi yang awalnya baik dan mampu melayani beban dengan baik, bisa jadi menjadi tidak sesuai lagi dengan keadaan pembebanan saat ini.

Analisa aliran daya adalah penentuan atau perhitungan yang ditujukan untuk mengetahui tegangan, arus, daya aktif, daya reaktif dan faktor daya yang terdapat pada berbagai titik dalam suatu jaringan sistem tenaga listrik pada keadaan pengoperasian normal, baik yang sedang berjalan maupun yang diharapkan akan terjadi di masa yang akan datang [1].

Metode Newton-Raphson merupakan metode yang banyak digunakan, karena secara perhitungan jauh lebih efisien dan lebih praktis dibandingkan metode lainnya[2].

Software ETAP (Electrical Transient and Analysis Program) merupakan sebuah software yang digunakan untuk keperluan simulasi suatu jaringan tenaga listrik[3]. Salah satu kemampuan dari software ini dapat mensimulasikan aliran daya pada suatu sistem tenaga listrik

Penelitian ini bertujuan untuk mengetahui sistem kelistrikan PT. Pertamina (Persero) Refinery Unit IV Cilacap pada bagian penyulang 05EE0101A di area utilities II dengan menggunakan metode Newton Raphson pada software ETAP 12.6 melakukan mekanisme aliran daya mengenai kinerja daya aktif, daya reaktif, profil tegangan dan rugi-rugi daya setiap bus pada sistem dan memberikan 
masukan untuk optimasi kondisi sistem kelistrikan setelah dilakukannya mekanisme analisa aliran daya.

\section{KAJIAN PUSTAKA}

\section{A. Studi Aliran Daya}

Studi aliran daya di dalam sistem tenaga listrik merupakan studi yang penting. Studi aliran daya mengungkapkan kinerja dan aliran daya (nyata dan reaktif) untuk keadaan tertentu tatkala sistem bekerja saat tunak (steady state). Studi aliran daya juga memberikan informasi mengenai beban saluran transmisi di sistem, tegangan di setiap lokasi evaluasi regulasi kinerja sistem tenaga listrik dan bertujuan untuk menentukan besarnya daya nyata (real power), daya reaktif (reactive power) di berbagai titik pada sistem daya yang dalam keadaan berlangsung atau diharapkan untuk operasi normal [4].

\section{B. Metode Newton-Raphson}

Dalam metode Newton-Raphson secara luas digunakan untuk permasalahan non linear. Penyelesaian persamaan ini menggunakan permasalahan yang linear dengan solusi pendekatan (Gbr 1). Metode ini dapat diaplikasikan untuk satu persamaan atau beberapa persamaan dengan beberapa variabel yang tidak diketahui.

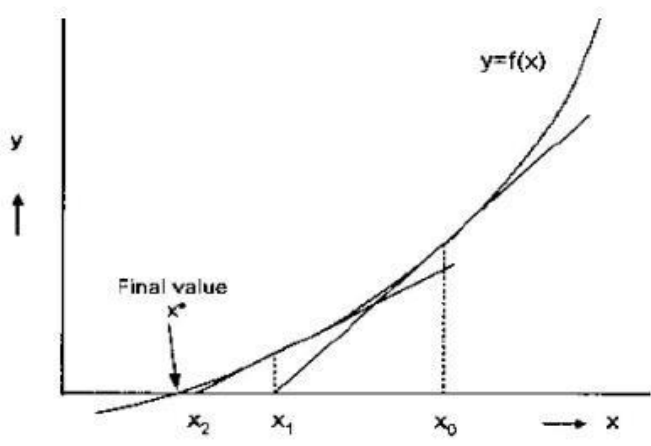

Gbr 1. Kurva Metode Newton-Raphson

\section{Jatuh Tegangan}

Jatuh tegangan merupakan besarnya tegangan yang hilang pada suatu penghantar. Jatuh tegangan pada saluran tenaga listrik secara umum berbanding lurus dengan panjang saluran dan beban serta berbanding terbalik dengan luas penampang penghantar. Tegangan jatuh ditimbulkan oleh arus yang mengalir melalui tahanan kawat. Tegangan jatuh $\mathrm{V}$ pada penghantar semakin besar jika arus I di dalam penghantar semakin besar dan jika tahanan penghantar Rl semakin besar pula.

\section{Tap Changer Transformator}

Tap changer adalah salah satu bagian utama dari Transformator Tenaga yang berfungsi untuk melayani pengaturan tegangan trafo tersebut, dengan cara memilih/merubah rasio tegangan, perubahan rasio (perbandingan transformasi) antara kumparan primer dan sekunder, untuk mendapatkan tegangan operasi disisi sekunder sesuai dengan yang diinginkan, kualitas (besarnya) tegangan pelayanan disisi sekunder dapat berubah karena tegangan sistem yang berubah-ubah akibat dari pembebanan ataupun kondisi sistem, pada perubahan yang diatur oleh tap changer adalah perubahan dengan range kecil antara $+10-15 \%$ dari tegangan dasar trafo tersebut [5].

\section{E. Electrical Transient and Analysis Program (ETAP)}

ETAP adalah suatu software analisis yang komprehensif untuk mendesain dan mensimulasikan suatu sistem rangkaian tenaga [3]. Analisis yang dapat digunakan ETAP antara lain load flow, short circuit, stabilitas transien, dll. Untuk menganalisa suatu rangkaian diperlukan data rangkaian yang lengkap dan akurat sehingga hasil perhitungan dapat dipertanggungjawabkan.

\section{Metodologi Penelitian}

Dalam penelitian analisa aliran daya sistem tenaga listrik pada bagian penyulang 05EE0101A di area utilities II PT. Pertamina (Persero) Refinery Unit IV Cilacap didasarkan pada beberapa tahapan penelitian (Gbr 2).

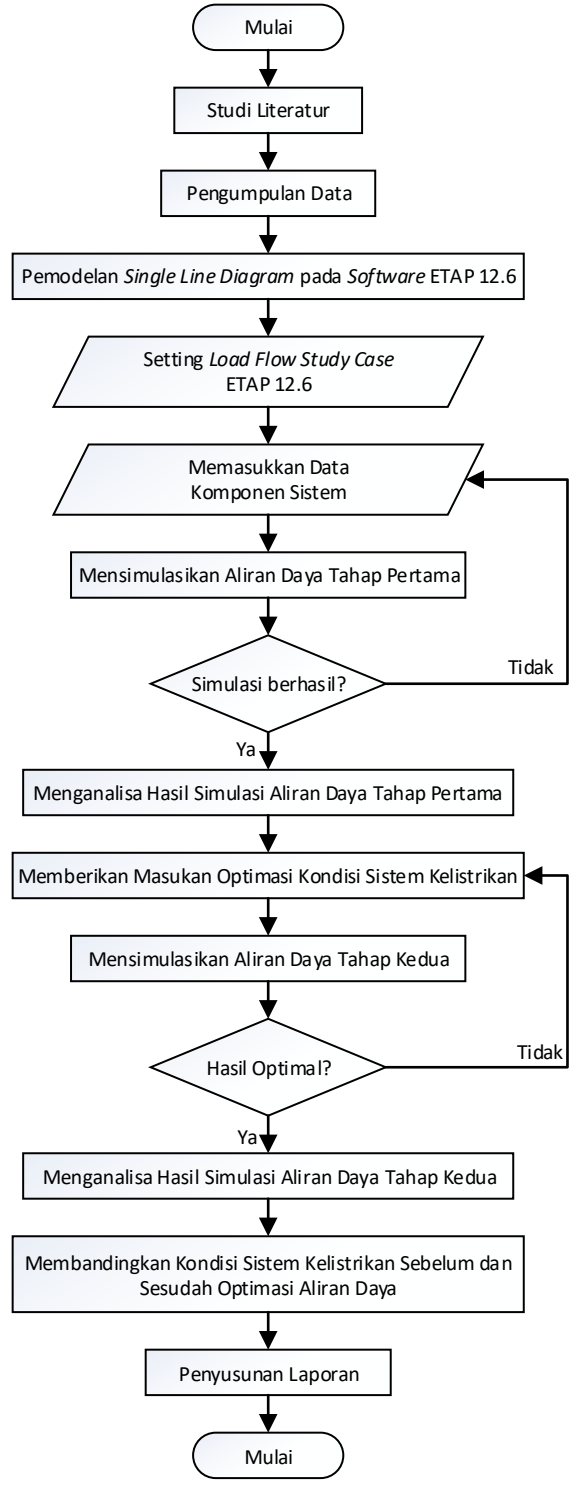

Gbr 2. Flowchart Penelitian

\section{A. Pemodelan Jaringan}

Berdasarkan data-data komponen yang ada, dilakukan pemodelan dalam bentuk single line diagram dari sistem kelistrikan di PT. Pertamina (Persero) Refinery Unit IV pada bagian penyulang 05EE0101A di area utilities II dalam software ETAP 12.6 (Gbr 3). Selanjutnya akan 
dilakukan simulasi dan analisa aliran daya dengan menggunakan metode Newton-Raphson dari hasil kondisi sistem.

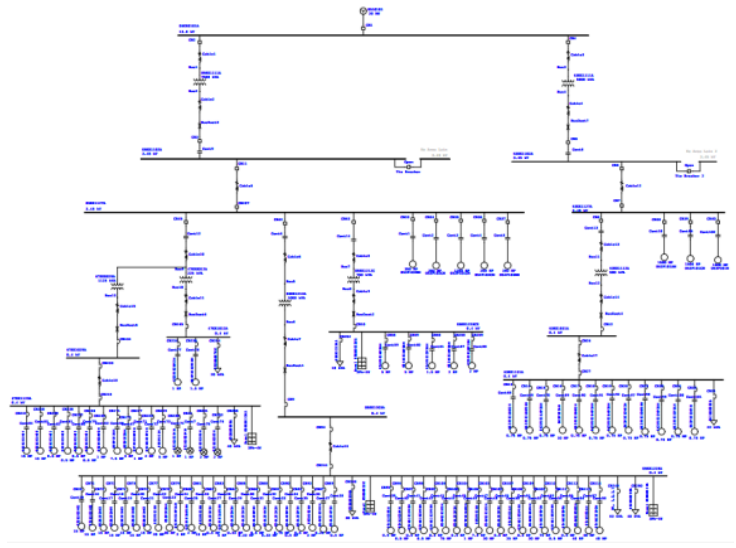

Gbr 3. Pemodelan Single Line Diagram pada ETAP

Pada area utilities II bagian penyulang 05EE0101A terdapat 3 sub station yang tersebar di berbagai area, yaitu:

- 05SS11, merupakan sub station dimana penyulang 13.8 $\mathrm{kV}$ berada dan sekaligus switchgear $3.45 \mathrm{kV}$ berada. Penyulang $13.8 \mathrm{kV}$ ini terhubung ke output generator $13.8 \mathrm{kV}$, Main Feeder $13.8 \mathrm{kV}$ ke Power Transformer dari sub station. Switchgear $3.45 \mathrm{kV}$ ini terhubung ke MCC $3.45 \mathrm{kV}$ untuk motor-motor dengan kapasitas diatas $200 \mathrm{HP}$ dan Power Transformator $13.8 \mathrm{kV} / 3.48 \mathrm{kV}$.

- 05SS12, merupakan sub station outgoing feeder dari 05SS11, dimana sub station ini melayani switchgear 0.4 $\mathrm{kV}$ yang menghubungkan Power Transformator 3.45 $\mathrm{kV} / 0.4 \mathrm{kV}$, MCC $0.4 \mathrm{kV}$ untuk motor-motor dengan kapasitas sampai $200 \mathrm{HP}$, panel sistem dan beban statik lainnya.

- 63SS11, merupakan sub station dimana switchgear 3.45 $\mathrm{kV}$ berada yang melayani Switchgear $3.45 \mathrm{kV}$ dan MCC $3.45 \mathrm{kV}$, outgoing feeder ke Power Transformator 3.45 $\mathrm{kV} / 0.4 \mathrm{kV}$ dan MCC $0.4 \mathrm{kV}$.

\section{B. Data Peralatan}

Unit utilitas II ini memiliki beberapa peralatan penting pada saat pengoperasian, yaitu generator dan transformator Generator yang digunakan yaitu generator uap (Tbl 1). Selanjutnya transformator yang ada di area ini terdiri dari 7 buah transformator yang digunakan selama pengoperasian jaringan (Tbl 2).

Tbl 1. Data Generator

\begin{tabular}{ll}
\hline & Generator 051G101 \\
\hline Tipe & Steam Turbo \\
\hline Faktor Daya & 0.8 \\
\hline Tegangan & $13.8 \mathrm{kV}$ \\
\hline Kapasitas & $20 \mathrm{MW} / 25 \mathrm{MVA}$ \\
\hline Kecepatan & $3000 \mathrm{RPM}$ \\
\hline Frekuensi & $50 \mathrm{~Hz}$ \\
\hline
\end{tabular}

Tb1 2. Data Transformator

\begin{tabular}{|c|c|c|c|c|}
\hline \multirow{2}{*}{ ID } & \multirow{2}{*}{ Area } & \multicolumn{3}{|c|}{ Rating } \\
\hline & & HV & $\mathbf{L V}$ & Kapasitas \\
\hline 05EE1111A & $05 \mathrm{SS} 11$ & $13.8 \mathrm{kV}$ & $3.45 \mathrm{kV}$ & $7500 \mathrm{kVA}$ \\
\hline 05EE1212A & $05 \mathrm{SS} 12$ & $3.45 \mathrm{kV}$ & $0.4 \mathrm{kV}$ & $1000 \mathrm{kVA}$ \\
\hline 05EE1212C & $05 \mathrm{SS} 12$ & $3.45 \mathrm{kV}$ & $0.4 \mathrm{kV}$ & $750 \mathrm{kVA}$ \\
\hline 47EE0012A & $05 \mathrm{SS} 11$ & $3.45 \mathrm{kV}$ & $0.4 \mathrm{kV}$ & $225 \mathrm{kVA}$ \\
\hline 63EE1111A & 63SS11 & $13.8 \mathrm{kV}$ & $3.45 \mathrm{kV}$ & $5000 \mathrm{kVA}$ \\
\hline 63EE1112A & 63SS11 & $3.45 \mathrm{kV}$ & $0.4 \mathrm{kV}$ & $500 \mathrm{kVA}$ \\
\hline 67EE0029A & 05SS11 & $3.45 \mathrm{kV}$ & $0.4 \mathrm{kV}$ & $1125 \mathrm{kVA}$ \\
\hline
\end{tabular}

\section{Data Bus}

Unit utilitas II ini memiliki 13 bus dengan tegangan yang bervariasi ( $\mathrm{Tbl} 3)$.

Tbl 3. Data Bus

\begin{tabular}{clc}
\hline ID & \multicolumn{1}{c}{ Tipe } & Tegangan $(\mathbf{k V})$ \\
\hline 05EE0101A & Penyulang & 13.8 \\
\hline 05EE1102A & Switchgear & 3.45 \\
\hline 05EE1127A & MCC & 3.45 \\
\hline 05EE1203A & Switchgear & 0.4 \\
\hline 05EE1228A & MCC & 0.4 \\
\hline 05EE1228CZ & MCC & 0.4 \\
\hline 47EE1012A & MCC & 0.4 \\
\hline 63EE1102A & Switchgear & 3.45 \\
\hline 63EE1127A & MCC & 3.45 \\
\hline 63EE1031A & Switchgear & 0.4 \\
\hline 63EE1131A & MCC & 0.4 \\
\hline 67EE1029A & Switchgear & 0.4 \\
\hline 67EE1129A & MCC & 0.4 \\
\hline
\end{tabular}

\section{Data Beban}

Pembagian beban di area ini dibagi menjadi beban motor dan beban statik. Beban motor di area ini memiliki tegangan operasi $0,4 \mathrm{kV}$ dan $3,45 \mathrm{kV}$ yang dicover ke dalam 2 area ( $\mathrm{Tbl} 4)$

Tbl 4. Jumlah Beban Motor Utilities II

\begin{tabular}{lccc}
\hline \multicolumn{1}{c}{ Jenis } & Tegangan & Area & Jumlah \\
\hline Motor Induksi & $3.45 \mathrm{kV}$ & $05 \mathrm{SS} 11$ & 5 \\
\hline Motor Induksi & $0.4 \mathrm{kV}$ & $05 \mathrm{SS} 11$ & 17 \\
\hline Motor Operated Valve & $0.4 \mathrm{kV}$ & $05 \mathrm{SS} 11$ & 4 \\
\hline Motor Induksi & $0.4 \mathrm{kV}$ & $05 \mathrm{SS} 12$ & 44 \\
\hline Motor Induksi & $3.45 \mathrm{kV}$ & $63 \mathrm{SS} 11$ & 3 \\
\hline Motor Induksi & $0.4 \mathrm{kV}$ & $63 \mathrm{SS} 11$ & 12 \\
\hline
\end{tabular}

Selain beban motor, area ini juga memiliki 11 buah beban statik yang tersebar ke dalam 3 area (Tbl 5).

Tbl 5. Jumlah Beban Statik Utilities II

\begin{tabular}{cc}
\hline Area & Jumlah \\
\hline $05 S S 11$ & 3 \\
\hline $05 S S 12$ & 7 \\
\hline $63 S S 11$ & 1 \\
\hline
\end{tabular}

\section{HASIL DAN PEMBAHASAN}

\section{A. Pengaturan Parameter Software ETAP}

Tinjauan simulasi dilakukan pada saat sistem berjalan dalam keadaan normal dengan beban berjalan seluruhnya secara maksimal. Aliran daya sistem kelistrikan dilakukan perhitungan dengan menggunakan metode NewtonRaphson pada software ETAP, dengan maksimum iterasi 5, precision of solution 0.0001 , frekuensi sistem $50 \mathrm{~Hz}$ dan unit sistem English.

Pengaturan simulasi peringatan yang digunakan untuk memberitahukan kondisi sistem kelistrikan yang telah ditentukan berdasarkan standar PLN (SPLN 1:1995) dimana batas toleransi naik tegangan (over voltage) sebesar $+5 \%$ dan batas toleransi turun tegangan (under voltage) sebesar $-10 \%$.

Tb1 6. Keterangan Alert Tegangan

\begin{tabular}{ccc}
\hline Bus Voltage & Critical (\%) & Marginal (\%) \\
\hline Over Voltage & 105 & 102 \\
\hline Under Voltage & 90 & 95 \\
\hline
\end{tabular}




\section{B. Hasil Analisa Aliran Daya}

Hasil simulasi pada kondisi eksisting, terdapat 3 komponen yang mengalami kondisi under voltage. Selain itu, terdapat kondisi overload pada Cable4 (Tbl 7).

Tb1 7. Hasil Alert Report ETAP Tahap Pertama

ID Tipe Condition Rating Unit Operating $\begin{gathered}\% \\ \text { Operating }\end{gathered}$ \begin{tabular}{lllllcc}
\hline 05EE1203A & Bus & Under Voltage & 0.400 & $\mathrm{kV}$ & 0.374 & 93.6
\end{tabular} \begin{tabular}{lllllll}
\hline 05EE1228A & Bus & Under Voltage & 0.400 & $\mathrm{kV}$ & 0.373 & 93.3
\end{tabular} \begin{tabular}{ccccccc} 
Bus6 & Bus & Under Voltage & 0.400 & $\mathrm{kV}$ & 0.379 & 94.7 \\
\hline
\end{tabular} \begin{tabular}{lllllll}
\hline Cable 4 & Cable & Overload & 658.913 & A & 677.858 & 102.9
\end{tabular}

Hasil selanjutnya mengenai hasil inti analisa aliran daya pada setiap bus dan percabangan yang ada pada sistem kelistrikan yang dianalisa. Hasil ini menjelaskan mengenai beban serta pembangkit yang terhubung pada jaringan, serta besar daya yang mengalir pada saluran antara satu bus dengan bus yang lainnya. Dalam hasil analisa aliran daya tahap pertama sistem kelistrikan PT. Pertamina (Persero) Refinery Unit IV pada bagian penyulang 05EE0101A di area utilities II menunjukkan kondisi drop tegangan terbesar terjadi pada bus 05EE1228A dengan rating 93.29\% atau turun $6.71 \%$ dari tegangan nominal. Namun kondisi ini masih dalam batas marginal, sesuai standar PLN (SPLN 1:1995) dimana batas maksimum turun tegangan sebesar $10 \%$ dari tegangan nominal.

Untuk meningkatkan aliran daya agar terjadi tingkat operasi aliran daya yang optimal maka dilakukan perbaikan, diantaranya:

- Menentukan Posisi Tap Changer Transformator 05EE1111A

- Menentukan Posisi Tap Changer Transformator $63 \mathrm{EE} 1111 \mathrm{~A}$

- Menentukan Posisi Tap Changer Transformator 05EE1212A

- Menentukan Luas Penampang Cable4
Hasil analisa daya tahap kedua dilakukan sebagai masukan untuk sistem kedepannya setelah dilakukan analisa aliran daya tahap pertama dimana beberapa komponen yang mengalami permasalahan dilakukan perbaikan dengan cara merubah posisi tap changer pada beberapa unit transformator dan pergantian unit Cable4 dikarenakan pada analisa aliran daya tahap pertama unit Cable4 mengalami overload.

Pada bus 05EE1203A mengalami peningkatan tegangan menjadi $98.87 \%$, pada bus 05EE1228A mengalami peningkatan tegangan sebesar $98.6 \%$. Pada Cable4 sudah dalam kondisi normal.

Hasil inti analisa aliran daya tahap kedua sistem kelistrikan PT. Pertamina (Persero) Refinery Unit IV pada bagian penyulang 05EE0101A di area utilities II setelah dilakukan perbaikan pada beberapa komponen yang sebelumnya mengalami permasalahan menunjukkan beberapa hasil sebagai berikut:

- Generator 051G101 menyalurkan daya aktif sebesar 6.632 MW dari maksimum kapasitas $20 \mathrm{MW}$ atau $33.16 \%$ dan daya reaktif sebesar 3.059 MVAR dari maksimum kapasitas 25 MVAR atau $12.23 \%$.

- Aliran daya terbesar mengalir dari penyulang 05EE0101A menuju bus3 dengan daya aktif sebesar 3.688 MW dan daya reaktif sebesar 1.651 MVAR.

- Pemakaian beban terbesar berada pada bus 63EE1127A dengan daya aktif sebesar 3.579 MW dan daya reaktif sebesar 1.466 MVAR.

- Kondisi drop tegangan terbesar terjadi pada bus 05EE1228A dengan rating $98.60 \%$ atau turun $1.4 \%$ dari tegangan nominal. Pada analisa aliran daya tahap pertama dimana bus 05EE1228A ini mengalami drop tegangan terbesar, pada analisa aliran daya tahap kedua ini bus tersebut mengalami optimasi yang signifikan dengan peningkatan sebesar $5.31 \%$.

Tbl 8. Data Hasil Aliran Daya

\begin{tabular}{|c|c|c|c|c|c|c|c|c|c|c|}
\hline \multirow{2}{*}{ ID } & \multirow{2}{*}{$\mathbf{k V}$} & \multirow{2}{*}{ ID } & \multicolumn{4}{|c|}{ Tahap Pertama } & \multicolumn{4}{|c|}{ Tahap Kedua } \\
\hline & & & MW & MVAR & Amp & $\% \mathbf{P F}$ & MW & MVAR & Amp & $\% \mathrm{PF}$ \\
\hline \multirow[t]{2}{*}{ 05EE0101A } & \multirow[t]{2}{*}{13.8} & Bus1 & 2.923 & 1.407 & 135.7 & 90.1 & 2.944 & 1.408 & 136.5 & 90.2 \\
\hline & & Bus3 & 3.694 & 1.661 & 169.5 & 91.2 & 3.688 & 1.651 & 169.0 & 91.3 \\
\hline \multirow[t]{2}{*}{ 05EE1102A } & \multirow[t]{2}{*}{3.45} & Bus2 & -2.889 & -1.331 & 542.9 & 90.8 & -2.912 & -1.335 & 532.5 & 90.9 \\
\hline & & 05EE1127A & 2.889 & 1.331 & 542.9 & 90.8 & 2.912 & 1.335 & 532.5 & 90.9 \\
\hline \multirow[t]{4}{*}{ 05EE1127A } & \multirow[t]{4}{*}{3.45} & 05EE1102A & -2.888 & -1.330 & 542.9 & 90.8 & -2.910 & -1.334 & 532.5 & 90.9 \\
\hline & & Bus5 & 0.682 & 0.357 & 131.5 & 88.6 & 0.700 & 0.362 & 131.1 & 88.8 \\
\hline & & Bus7 & 0.019 & 0.009 & 3.6 & 90.2 & 0.019 & 0.009 & 3.5 & 90.4 \\
\hline & & Bus9 & 0.131 & 0.031 & 23.1 & 97.3 & 0.136 & 0.031 & 23.2 & 97.4 \\
\hline \multirow[t]{2}{*}{ 05EE1203A } & \multirow[t]{2}{*}{0.4} & Bus6 & -0.666 & -0.313 & 1134.6 & 90.5 & -0.684 & -0.319 & 1102.4 & 90.6 \\
\hline & & 05EE1228A & 0.666 & 0.313 & 1134.6 & 90.5 & 0.684 & 0.319 & 1102.4 & 90.6 \\
\hline 05EE1228A & 0.4 & 05EE1203A & -0.664 & -0.311 & 1134.6 & 90.5 & -0.683 & -0.318 & 1102.4 & 90.6 \\
\hline 05EE1228C & 0.4 & Bus8 & -0.019 & -0.009 & 30.9 & 90.2 & -0.019 & -0.009 & 30.4 & 90.4 \\
\hline 47EE1012A & 0.4 & Bus10 & -0.021 & -0.002 & 31.7 & 99.7 & -0.022 & -0.002 & 32.3 & 99.7 \\
\hline \multirow{2}{*}{ 63EE1031A } & \multirow[t]{2}{*}{0.4} & Bus12 & -0.027 & -0.011 & 43.7 & 92.5 & -0.027 & -0.011 & 43.2 & 92.8 \\
\hline & & \begin{tabular}{|l|}
$63 E E 1131 A$ \\
\end{tabular} & 0.027 & 0.011 & 43.7 & 92.5 & 0.027 & 0.011 & 43.2 & 92.8 \\
\hline \multirow[t]{2}{*}{ 63EE1102A } & \multirow[t]{2}{*}{3.45} & Bus4 & -3.608 & -1.478 & 677.9 & 92.5 & -3.608 & -1.478 & 659.2 & 92.5 \\
\hline & & 63EE1127A & 3.608 & 1.478 & 677.9 & 92.5 & 3.608 & 1.478 & 659.2 & 92.5 \\
\hline \multirow[t]{2}{*}{ 63EE1127A } & \multirow[t]{2}{*}{3.45} & 63EE1102A & -3.606 & -1.478 & 677.9 & 92.5 & -3.607 & -1.478 & 659.2 & 92.5 \\
\hline & & Bus11 & 0.027 & 0.011 & 5.1 & 92.4 & 0.027 & 0.011 & 5.0 & 92.7 \\
\hline 63EE1131A & 0.4 & 63EE1031A & -0.027 & -0.011 & 43.7 & 92.5 & -0.027 & -0.011 & 43.2 & 92.8 \\
\hline \multirow[t]{2}{*}{ 67EE1029A } & \multirow[t]{2}{*}{0.4} & Bus13 & -0.108 & -0.028 & 167.7 & 96.9 & -0.112 & -0.028 & 168.1 & 97.1 \\
\hline & & 67EE1129A & 0.108 & 0.028 & 167.7 & 96.9 & 0.112 & 0.028 & 168.1 & 97.1 \\
\hline 67EE1129A & 0.4 & 67EE1029A & -0.108 & -0.028 & 167.7 & 96.9 & -0.112 & -0.028 & 168.1 & 97.1 \\
\hline \multirow[t]{2}{*}{ Bus1 } & \multirow[t]{2}{*}{13.8} & 05EE0101A & -2.923 & -1.406 & 135.7 & 90.1 & -2.944 & -1.408 & 136.5 & 90.2 \\
\hline & & Bus2 & 2.923 & 1.406 & 135.7 & 90.1 & 2.944 & 1.408 & 136.5 & 90.2 \\
\hline
\end{tabular}




\begin{tabular}{|c|c|c|c|c|c|c|c|c|c|c|}
\hline \multirow{2}{*}{ ID } & \multirow{2}{*}{$\mathbf{k V}$} & \multirow{2}{*}{ ID } & \multicolumn{4}{|c|}{ Tahap Pertama } & \multicolumn{4}{|c|}{ Tahap Kedua } \\
\hline & & & MW & MVAR & Amp & $\% \mathrm{PF}$ & MW & MVAR & Amp & $\% \mathrm{PF}$ \\
\hline \multirow[t]{2}{*}{ Bus2 } & \multirow[t]{2}{*}{3.45} & 05EE1102A & 2.893 & 1.333 & 542.9 & 90.8 & 2.915 & 1.338 & 532.5 & 90.9 \\
\hline & & Bus1 & -2.893 & -1.333 & 542.9 & 90.8 & -2.915 & -1.338 & 532.5 & 90.9 \\
\hline \multirow[t]{2}{*}{ Bus3 } & \multirow[t]{2}{*}{13.8} & 05EE0101A & -3.689 & -1.657 & 169.5 & 91.2 & -3.682 & -1.647 & 169.0 & 91.3 \\
\hline & & Bus4 & 3.689 & 1.657 & 169.5 & 91.2 & 3.682 & 1.647 & 169.0 & 91.3 \\
\hline \multirow[t]{2}{*}{ Bus4 } & \multirow[t]{2}{*}{3.45} & 63EE1102A & 3.620 & 1.487 & 677.9 & 92.5 & 3.617 & 1.486 & 659.2 & 92.5 \\
\hline & & Bus3 & -3.620 & -1.487 & 677.9 & 92.5 & -3.617 & -1.486 & 659.2 & 92.5 \\
\hline \multirow[t]{2}{*}{ Bus5 } & \multirow[t]{2}{*}{3.45} & 05EE1127A & -0.679 & -0.355 & 131.5 & 88.6 & -0.697 & -0.360 & 131.1 & 88.9 \\
\hline & & Bus6 & 0.679 & 0.355 & 131.5 & 88.6 & 0.697 & 0.360 & 131.1 & 88.9 \\
\hline \multirow[t]{2}{*}{ Bus6 } & \multirow[t]{2}{*}{0.4} & 05EE1203A & 0.673 & 0.318 & 1134.6 & 90.4 & 0.691 & 0.325 & 1102.4 & 90.5 \\
\hline & & Bus5 & -0.673 & -0.318 & 1134.6 & 90.4 & -0.691 & -0.325 & 1102.4 & 90.5 \\
\hline \multirow[t]{2}{*}{ Bus7 } & \multirow[t]{2}{*}{3.45} & 05EE1127A & -0.019 & -0.009 & 3.6 & 90.2 & -0.019 & -0.009 & 3.5 & 90.4 \\
\hline & & Bus8 & 0.019 & 0.009 & 3.6 & 90.2 & 0.019 & 0.009 & 3.5 & 90.4 \\
\hline \multirow[t]{2}{*}{ Bus8 } & \multirow[t]{2}{*}{0.4} & 05EE1228CZ & 0.019 & 0.009 & 30.9 & 90.3 & 0.019 & 0.009 & 30.4 & 90.5 \\
\hline & & Bus7 & -0.019 & -0.009 & 30.9 & 90.3 & -0.019 & -0.009 & 30.4 & 90.5 \\
\hline \multirow[t]{3}{*}{ Bus9 } & \multirow[t]{3}{*}{3.45} & 05EE1127A & -0.131 & -0.031 & 23.1 & 97.3 & -0.136 & -0.031 & 23.2 & 97.4 \\
\hline & & Bus10 & 0.021 & 0.002 & 3.7 & 99.6 & 0.022 & 0.002 & 3.7 & 99.7 \\
\hline & & Bus13 & 0.110 & 0.030 & 19.4 & 96.6 & 0.113 & 0.030 & 19.5 & 96.8 \\
\hline \multirow[t]{2}{*}{ Bus10 } & \multirow[t]{2}{*}{0.4} & 47EE1012A & 0.021 & 0.002 & 31.7 & 99.7 & 0.022 & 0.002 & 32.3 & 99.7 \\
\hline & & Bus9 & -0.021 & -0.002 & 31.7 & 99.7 & -0.022 & -0.002 & 32.3 & 99.7 \\
\hline \multirow[t]{2}{*}{ Bus11 } & \multirow[t]{2}{*}{3.45} & 63EE1127A & -0.027 & -0.011 & 5.1 & 92.4 & -0.027 & -0.011 & 5.0 & 92.7 \\
\hline & & Bus12 & 0.027 & 0.011 & 5.1 & 92.4 & 0.027 & 0.011 & 5.0 & 92.7 \\
\hline \multirow[t]{2}{*}{ Bus12 } & \multirow[t]{2}{*}{0.4} & 63EE1031A & 0.027 & 0.011 & 43.6 & 92.5 & 0.027 & 0.011 & 43.2 & 92.8 \\
\hline & & Bus11 & -0.027 & -0.011 & 43.6 & 92.5 & -0.027 & -0.011 & 43.2 & 92.8 \\
\hline \multirow[t]{2}{*}{ Bus13 } & \multirow[t]{2}{*}{0.4} & 67EE1029A & 0.110 & 0.029 & 167.7 & 96.7 & 0.113 & 0.029 & 168.1 & 96.9 \\
\hline & & Bus9 & -0.110 & -0.029 & 167.7 & 96.7 & -0.113 & -0.029 & 168.1 & 96.9 \\
\hline
\end{tabular}

\section{Rugi-Rugi Daya}

Selain itu rugi-rugi daya (losses) menjadi pengaruh penting dalam suatu sistem kelistrikan. Bus 63EE1111A memiliki losses terbesar dalam sistem (Tbl 9).

Hasil rugi-rugi daya yang terjadi pada setiap saluran pada tahap kedua mengalami penurunan. Pada bus
63EE1111A terjadi losses terbesar sebesar $65.2 \mathrm{~kW}$ dan 161.2 kVAR. Total losses daya aktif $134.5 \mathrm{~kW}$ dan total losses daya reaktif 293.1 kVAR. Pada kondisi profil tegangan saluran dari dan menuju mengalami peningkatan yang signifikan dengan persentase pengiriman sebesar $98 \%$ sampai dengan $100 \%$ tingkat operasi.

Tb1 9. Data Hasil Rugi-Rugi Saluran

\begin{tabular}{|c|c|c|c|c|c|c|c|c|}
\hline \multirow{3}{*}{ ID } & \multicolumn{4}{|c|}{ Tahap Pertama } & \multicolumn{4}{|c|}{ Tahap Kedua } \\
\hline & \multicolumn{2}{|c|}{ Losses } & \multicolumn{2}{|c|}{$\%$ Bus Voltage } & \multicolumn{2}{|c|}{ Losses } & \multicolumn{2}{|c|}{ \% Bus Voltage } \\
\hline & kW & kVAR & From & To & kW & KVAR & From & To \\
\hline Cable 1 & 0.6 & 0.4 & 100.0 & 100.0 & 0.6 & 0.4 & 100.0 & 100.0 \\
\hline Cable3 & 5.3 & 4.0 & 100.0 & 99.8 & 5.2 & 4.0 & 100.0 & 99.8 \\
\hline Cable2 & 3.6 & 2.3 & 98.1 & 98.2 & 3.5 & 2.2 & 100.7 & 100.8 \\
\hline Cable5 & 1.8 & 1.2 & 98.1 & 98.0 & 1.7 & 1.1 & 100.7 & 100.6 \\
\hline Cable6 & 3.2 & 2.1 & 98.0 & 97.5 & 3.1 & 2.0 & 100.6 & 100.1 \\
\hline Cable 8 & 0.0 & 0.0 & 98.0 & 98.0 & 0.0 & 0.0 & 100.6 & 100.6 \\
\hline Cable 10 & 0.1 & 0.1 & 98.0 & 97.9 & 0.2 & 0.1 & 100.6 & 100.5 \\
\hline Cable 7 & 7.1 & 5.6 & 93.6 & 94.7 & 6.7 & 5.2 & 98.9 & 100.0 \\
\hline Cable16 & 1.8 & 1.4 & 93.6 & 93.3 & 1.7 & 1.3 & 98.9 & 98.6 \\
\hline Cable 9 & 0.0 & 0.0 & 97.7 & 97.9 & 0.0 & 0.0 & 100.3 & 100.5 \\
\hline Cable 11 & 0.1 & 0.0 & 97.5 & 97.7 & 0.1 & 0.0 & 100.1 & 100.3 \\
\hline Cable14 & 0.0 & 0.0 & 95.9 & 96.0 & 0.0 & 0.0 & 98.7 & 98.7 \\
\hline Cable17 & 0.0 & 0.0 & 95.9 & 95.9 & 0.0 & 0.0 & 98.7 & 98.6 \\
\hline Cable 4 & 12.6 & 8.2 & 96.3 & 96.6 & 9.2 & 7.6 & 99.0 & 99.3 \\
\hline Cable 12 & 1.1 & 0.7 & 96.3 & 96.2 & 1.1 & 0.7 & 99.0 & 98.9 \\
\hline Cable13 & 0.0 & 0.0 & 96.2 & 96.2 & 0.0 & 0.0 & 98.9 & 98.9 \\
\hline Cable 15 & 1.6 & 1.2 & 96.1 & 97.6 & 1.6 & 1.2 & 98.7 & 100.2 \\
\hline Cable18 & 0.0 & 0.0 & 96.1 & 96.0 & 0.0 & 0.0 & 98.7 & 98.7 \\
\hline 05EE1111A & 29.5 & 72.9 & 100.0 & 98.2 & 28.4 & 70.1 & 100.0 & 100.8 \\
\hline 63EE1111A & 69.0 & 170.0 & 99.8 & 96.6 & 65.2 & 161.2 & 99.8 & 99.3 \\
\hline 05EE1212A & 6.4 & 37.0 & 97.5 & 94.7 & 6.0 & 35.0 & 100.1 & 100.0 \\
\hline 05EE1212C & 0.0 & 0.0 & 98.0 & 97.9 & 0.0 & 0.0 & 100.6 & 100.5 \\
\hline 47EE0012A & 0.0 & 0.1 & 97.9 & 97.7 & 0.0 & 0.1 & 100.5 & 100.3 \\
\hline 67EE0029A & 0.1 & 0.7 & 97.9 & 97.6 & 0.1 & 0.7 & 100.5 & 100.2 \\
\hline 63EE1112A & 0.0 & 0.1 & 96.2 & 96.0 & 0.0 & 0.1 & 98.9 & 98.7 \\
\hline Total & 144.0 & 308.4 & & & 134.5 & 293.1 & & \\
\hline
\end{tabular}




\section{Total Rugi-rugi Daya}

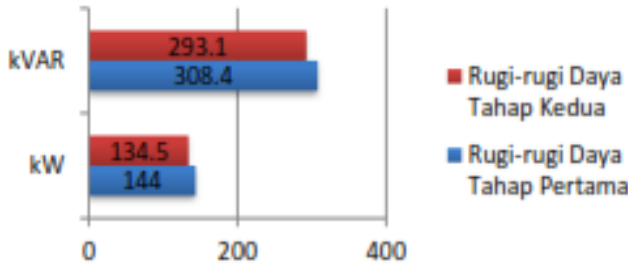

Gbr 4. Grafik Perbandingan Total Rugi-rugi Daya

Total rugi-rugi daya setelah adanya perbaikan menunjukkan angka yang signifikan, baik untuk daya aktif maupun daya reaktif (Gbr 4).

\section{Profil Tegangan}

Perbaikan yang telah dilakukan melalui simulasi memberikan dampak pula pada profil tegangan setiap bus. Berdasarkan hasil simulasi yang dilakukan, maka tegangan disetiap bus berada diatas $95 \%$ dari tegangan normalnya (Gbr 5).

\section{Profil Tegangan Bus}

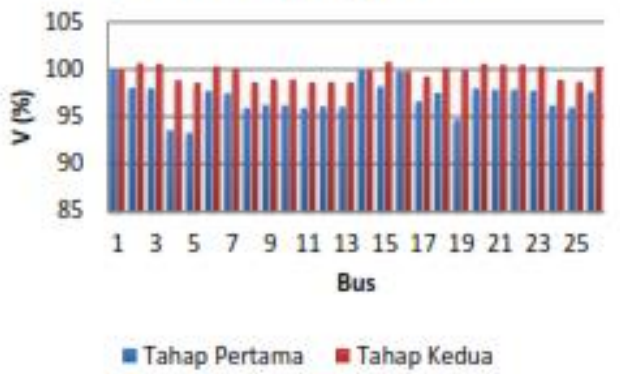

Gbr 5. Grafik Perbandingan Profil Tegangan Bus

\section{KESIMPULAN}

Kondisi sistem kelistrikan pada bagian penyulang 05EE0101A di area utilities II berdasarkan hasil simulasi menggunakan metode Newton-Raphson pada software ETAP 12.6 menunjukkan terdapat beberapa permasalahan dengan kondisi under voltage pada tiga bus, yaitu bus 05EE1203A, bus 05EE1228A dan bus6, dan terdapat kondisi overload pada Cable4.

Hasil simulasi aliran daya tahap pertama kondisi sistem eksisting, diperoleh total daya aktif sebesar 6.618 MW dan daya reaktif sebesar 3.068 MVAR, aliran daya terbesar mengalir dari penyulang 05EE0101A menuju bus3 dengan daya aktif sebesar 3.694 MW dan daya reaktif sebesar 1.661 MVAR. Hasil profil tegangan yang terjadi, drop tegangan yang terburuk ada pada bus 05EE1228A turun $6.71 \%$ dari tegangan nominal. Rugi-rugi daya yang terjadi pada seluruh sistem sebesar $144.0 \mathrm{~kW}$ daya aktif dan 308.4 kVAR daya reaktif, bus yang mengalami rugi-rugi daya terbesar berada pada bus 63EE1111A sebesar $69.0 \mathrm{~kW}$ daya aktif dan $170.0 \mathrm{kVAR}$ daya reaktif.

Hasil simulasi aliran daya tahap kedua setelah optimasi kondisi sistem, didapatkan hasil peningkatan daya aktif menjadi 6.632 MW dan penurunan daya reaktif menjadi 3.059 MVAR, aliran daya terbesar mengalir dari penyulang 05EE0101A menuju bus3 pada masukan trafo 63EE1111A mengalami penurunan daya aktif menjadi 3.688 MW dan daya reaktif menjadi 1.651 MVAR. Hasil profil tegangan terjadi peningkatan yang signifikan dimana profil tegangan semua bus sebesar 98\% sampai $100 \%$ tingkat pengiriman dan drop tegangan terburuk pada bus 05EE1228A turun $1.41 \%$ dari tegangan nominal, dengan ini terjadi peningkatan sebesar $5.31 \%$ dari tahap pertama. Rugi-rugi daya yang terjadi pada seluruh sistem mengalami penurunan daya aktif menjadi $134.5 \mathrm{~kW}$ dan penurunan daya reaktif menjadi $293.1 \mathrm{kVAR}$ daya reaktif, bus yang mengalami rugi-rugi daya terbesar berada pada bus 63EE1111A sebesar $65.2 \mathrm{~kW}$ daya aktif dan $161.2 \mathrm{kVAR}$ daya reaktif.

\section{REFERENSI}

[1] A. Belly, A. Dadan H, C. Agusman, and B. Lukman, "Daya Aktif, Reaktif \& Nyata," 2010.

[2] A. Hermawan, "Analisis Terhadap Performance Sistem Tenaga Listrik Memakai Metode Aliran Daya,” ELTEK, vol. 11, pp. 17-28, 2013.

[3] A. M. F. Fajar and I. Handayani. "Analisis Aliran Daya Dan Gangguan Hubung Singkat Sistem Kelistrikan Pabrik Tonasa V Di Pt Semen Tonasa Menggunakan Etap," 2012.

[4] D.D. Micu, S.F. Braicu, L. Czumbil, and D. Stet, "Load Flow and Short-Circuit Analysis in a Romanian 110 / 20 kV Retrofitted Substation,” pp. 0-5, 2016.

[5] H. Saadat, Power System Analysis, 1999.

\section{Biografi PENULIS}

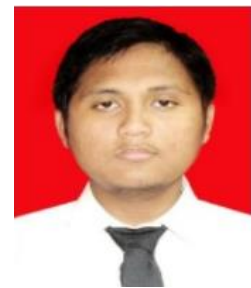

Fredo Otniel, lahir di Bekasi pada tanggal 5 Februari 1997. Saat ini sedang menempuh pendidikan sarjana di Jurusan Teknik Elektro, Universitas Siliwangi. Bidang penelitian yang ditekuni saat ini yaitu Sistem Tenaga. 